\title{
EUROPEAN UNION FUNDING FOR PRESERVATION OF RELIGIOUS CULTURAL HERITAGE IN POLAND
}

\author{
Joanna Rakowska ${ }^{\bowtie}$ \\ Warsaw University of Life Sciences - SGGW, Poland
}

\begin{abstract}
As there is a dynamic relation between religious cultural heritage, tourism and local development, the European Union supports preservation of religious heritage through regional policy funds available in Poland under operational programmes. The aim of the research was to define and look into the main outcomes of this support, based on qualitative and quantitative data from SIMIK 2007-2013 and central teleinformation system (CTS) SL2014 for 2014-2020. Findings show that the 618 projects for the preservation of religious cultural heritage in Poland comprised a very small share of all investments under operational programmes. They were also a very small share of the total value of all projects and of EU funding co-financing them. However, comparing the financial perspective of 2007-2013 and 2014-2020, there is an increase in the number of these investments and in the number of projects that obtained the best relation of EU funding to their total value, i.e. $85 \%$.
\end{abstract}

Key words: religious cultural heritage, EU funding, local development, tourism

JEL codes: Z32, L83, Z12

\section{INTRODUCTION}

Religious heritage is a significant element of cultural heritage in many social and economic contexts [Smith 2009, Fadare and Benson 2015]. Because of Polish history, tangible religious heritage, including sacral historical objects and their contents, composes a significant part of the national, regional and local cultural heritage [Rohrscheidt 2011]. Bearing the same qualities as cultural heritage, i.e. aesthetic, spiritual, social, and historical values, as well as symbolic and educational values [Cohen 2006, Throsby 2016], religious heritage is crucial for maintaining identity and traditions of local communities [International Council of Monuments and Sites 1999]. It is also a fundament for developing pilgrimage and religious tourism [Jackowski 2005,
Sołjan 2007, Kowalski and Ruszkowski 2011], which can stimulate local and regional economies - giving them momentum and further contributing to their development [Vukonić 1998, Richards 2001, Vukonic 2002, Małek 2003, Pytel 2010, Hełpa-Liszkowska 2013, MSiT RP 2015]. On the other hand, due to its growing commercialisation and environmental impact [McKercher and du Cross 2012, Raj and Griffin 2015], religious tourism can generate adverse effects, putting religious heritage at risk of being damaged or destroyed.

All the above-mentioned characteristics make religious heritage an important but rather fragile factor of tourism development, requiring support, protection and preservation. As there is a dynamic relation between religious heritage, tourism and development, 
the European Union provides support through its regional policy funding, available under operational programmes in eligible regions of the EU member states. Poland has obtained the biggest share of EU regional policy funding for eligible member states in financial perspectives of 2007-2013 and 2014-2020. However, no exact amount of EU funding was assigned to any particular category of beneficiaries, e.g. only churches or religious associations. There was also no funding allocated specifically to support projects connected with preservation of religious heritage. The funding was addressed to a wider range of beneficiaries and assigned to more general categories of investments. That is why there is a question as to the outcome of EU funding support for the preservation of religious heritage.

\section{AIM AND METHOD}

The main aim of the research was to define the outcome of EU funding support for the preservation of religious heritage in Poland under operational programmes 2007-2013 and 2014-2020. The main aim was supplemented by answers to the following sub-questions: How many and what kind of projects connected with the preservation of religious heritage were co-financed from EU funding? Under which programmes and actions were they co-financed? Who were the beneficiaries? Were there any regional differences?

Since the analysed investments required that the beneficiaries match with a domestic contribution to eligible costs and funds covering non-eligible costs in full if they occurred, the next question was: To what extend did the EU funding financially support realisation of the analysed projects? Were there any correlations between the total value of the projects and EU funding?

Due to its aim, the research is of explorative character. It is based on secondary, qualitative and quantitative data from the Ministry of Development databases SIMIK 2007-2013 (as of 31 December 2015) and SIMIK 2014-2020 (as of 30 September 2020), which look at EU funding in Poland. Methods of qualitative data analysis were applied to extract and analyse data on the character of the projects, while descriptive statistics were used to analyse the following categories of financial data: total value of projects, eligible costs, value of EU funding, and their relationships.

\section{RESULTS AND DISCUSSION}

Since 2007, 618 projects resulting in preservation of religious cultural heritage have been carried out in Poland with the support of EU regional policy funding. They comprised a very small share of all projects carried out in 2007-2013 and 2014-2020 financial perspectives $(0.2 \%$ and $0.5 \%$ respectively), and a very small share of total EU funding absorbed by Polish beneficiaries under operational programme 2007-2013 and 2014-2020 (0.3\% and 0.4\%, respectively).

Although the financial perspective of 2014-2020 is not yet over, most of the analysed projects were co-financed by EU funding under operational programmes 2014-2020 (60\%). And as this financial perspective is still on-going, this share will increase. In both financial perspectives investments in preservation of religious heritage were co-financed under Operational Programme Infrastructure and Environment (OP I\&E) and Regional Operational Programmes (ROP). Due to the general assumptions of EU regional policy, both OPs Infrastructure and Environment covered the whole country and were designed to co-finance projects of high total value, while ROPs were designed for each region individually and had no assumption on the total value of projects. Both OP I\&Es and ROPs could support investments up to $85 \%$ of their eligible costs.

Considering OP E\&Is, there was a significant increase in the number of the analysed projects carried out in 2007-2013 and 2014-2020. All investments in preservation of religious heritage in 2007-2013 and nearly all (except 2) in 2014-2020 were carried out by the Catholic Church. European Union structural funds were obtained for renovation and/or conservation of, for example: revalorization of the Krzeszów Cistercian Abbey with its surroundings; Bernardine monastery complex with the Basilica of the Assumption of the Blessed Virgin Mary in Leżajsk; the interior of the pearl of early Gothic sacral architecture - the Cathedral Basilica of the Nativity of the Blessed Virgin Mary in Sandomierz; the Jasna Góra Pauline Monastery in Częstochowa; the Basilica of the Dominican Order of St. Stanislaus in Lublin; objects of sacral wooden 
Rakowska, J. (2020). European Union funding for preservation of religious cultural heritage in Poland. Acta Sci. Pol. Oeconomia 19 (4), 113-120, DOI: 10.22630/ASPE.2020.19.4.47

Table 1. Descriptive statistics for EU funds supporting projects to preserve religious heritage under operational programmes 2007-2013 in Poland

\begin{tabular}{|c|c|c|c|c|c|c|c|c|}
\hline \multirow{2}{*}{ Source of EU funds 2007-2013 } & \multirow{2}{*}{$\begin{array}{l}\text { Number } \\
\text { of } \\
\text { projects }\end{array}$} & \multirow{2}{*}{$\begin{array}{l}\text { EU funds total } \\
\text { value } \\
\text { (million PLN) }\end{array}$} & \multicolumn{6}{|c|}{ EU funds per project (million PLN) } \\
\hline & & & $\min$ & $\max$ & range & $A V G$ & $M$ & $S D$ \\
\hline OP Infrastructure and Environment & 3 & 71.62 & 20.55 & 26.15 & 5.60 & 23.87 & 24.92 & 2.94 \\
\hline ROP Dolnośląskie & 25 & 50.77 & 0.06 & 13.69 & 13.64 & 2.03 & 0.90 & 2.94 \\
\hline ROP Kujawsko-pomorskie & 8 & 13.94 & 0.20 & 9.48 & 9.29 & 1.74 & 0.69 & 3.14 \\
\hline ROP Lubelskie & 26 & 93.51 & 0.66 & 10.00 & 9.34 & 3.60 & 2.43 & 2.70 \\
\hline ROP Lubuskie & 1 & 5.14 & - & - & - & 5.14 & - & - \\
\hline ROP Łódzkie & 3 & 64.49 & 2.04 & 40.19 & 38.15 & 21.50 & 22.26 & 19.09 \\
\hline ROP Małopolskie & 12 & 41.02 & 0.84 & 8.87 & 8.03 & 3.42 & 2.49 & 2.81 \\
\hline ROP Mazowieckie & 27 & 73.97 & 0.37 & 17.77 & 17.40 & 2.74 & 0.74 & 4.49 \\
\hline ROP Opolskie & 9 & 11.42 & 0.34 & 3.06 & 2.72 & 1.27 & 0.87 & 1.00 \\
\hline ROP Podkarpackie & 26 & 72.40 & 0.08 & 24.28 & 24.20 & 2.78 & 1.86 & 4.68 \\
\hline ROP Podlaskie & 9 & 45.85 & 0.28 & 11.59 & 11.30 & 5.09 & 5.00 & 3.88 \\
\hline ROP Pomorskie & 14 & 33.06 & 0.07 & 5.36 & 5.29 & 2.36 & 3.10 & 1.83 \\
\hline ROP Śląskie & 24 & 95.75 & 0.19 & 26.40 & 26.22 & 3.99 & 1.76 & 5.62 \\
\hline ROP Świętokrzyskie & 32 & 22.06 & 0.09 & 3.84 & 3.75 & 0.69 & 0.43 & 0.77 \\
\hline ROP Warmińsko-mazurskie & 9 & 8.41 & 0.15 & 2.33 & 2.18 & 0.93 & 0.72 & 0.66 \\
\hline ROP Wielkopolskie & 10 & 53.04 & 1.22 & 9.65 & 8.43 & 5.30 & 4.57 & 3.32 \\
\hline ROP Zachodnio-pomorskie & 10 & 17.64 & 0.63 & 3.86 & 3.22 & 1.76 & 1.49 & 0.95 \\
\hline All OPs & 248 & 774.08 & 0.06 & 40.19 & 40.13 & 3.12 & 1.49 & 4.99 \\
\hline
\end{tabular}

Source: Author's elaboration based on SIMIK 2007-2013 data.

architecture of the Wielkopolska region and the Kalisz Diocese; the complex of the three oldest churches in Gniezno; the Cathedral Basilica of the Assumption and historic post-Cistercian buildings in Pelplin; the 14th-century defensive and cathedral complex in Frombork; the historic Church of the Holy Spirit and All Saints Church in Warsaw; a wooden UNESCO monument - Church of the Holy Trinity (Church of Peace) in Świdnica; the largest Baroque Franciscan church in Poland - Church of the Annunciation to the Blessed Virgin Mary in Zamość; the monastery complex of St. Joseph in Gdańsk; wooden monuments of the Archdiocese of Gniezno; the Primatial Cathedral Basilica of the Assumption of the Blessed Virgin Mary and
Shrine of St. Adalbert (Royal Gniezno Cathedral) in Gniezno; wooden monuments of the Lubawa Region; the Basilica of the Holy Trinity in Kraków; the Gothic Basilica of St. James and St. Agnes in Nysa; Church of Our Lady Assumed into Heaven (St. Mary's Basilica) in Gdańsk; the cultural heritage of Western Pomerania; newly discovered, unique polychromes in the crypt of the Church of the Piarist Order of the Transfiguration of Christ; the historic collegiate Church of the Blessed Virgin Mary, Queen of the World in Stargard.

Other beneficiaries carried out only two projects preserving their religious heritage. Those were: Evangelical-Augsburg parish in Świdnica, who did the conservation and renovation of the wooden the Church of 
Rakowska, J. (2020). European Union funding for preservation of religious cultural heritage in Poland. Acta Sci. Pol. Oeconomia 19 (4), 113-120, DOI: 10.22630/ASPE.2020.19.4.47

Table 2. Share of EU funding in total value of projects to preserve religious heritage under operational programmes 2007-2013 in Poland

\begin{tabular}{|c|c|c|c|c|c|c|c|c|}
\hline \multirow{2}{*}{ Source of EU funds 2007-2013 } & \multirow{2}{*}{$\begin{array}{c}\text { Projects } \\
\text { total value } \\
\text { (million PLN) }\end{array}$} & \multirow{2}{*}{$\begin{array}{c}\text { EU funds } \\
\text { total value } \\
\text { (million PLN) }\end{array}$} & \multicolumn{6}{|c|}{ Share of EU funds in total value (\%) } \\
\hline & & & $\min$ & $\max$ & range & $A V G$ & $M$ & $S D$ \\
\hline OP Infrastructure and Environment & 86.4 & 71.62 & 80 & 85 & 5 & 83 & 84 & 3 \\
\hline ROP Dolnośląskie & 76.6 & 50.77 & 38 & 70 & 32 & 64 & 69 & 10 \\
\hline ROP Kujawsko-pomorskie & 23.8 & 13.94 & 23 & 84 & 61 & 60 & 67 & 19 \\
\hline ROP Lubelskie & 140.2 & 93.51 & 32 & 85 & 53 & 67 & 70 & 12 \\
\hline ROP Lubuskie & 5.14 & 5.14 & - & - & - & - & - & - \\
\hline ROP Łódzkie & 81.0 & 64.49 & 72 & 85 & 13 & 78 & 79 & 7 \\
\hline ROP Małopolskie & 73.8 & 41.02 & 33 & 64 & 31 & 52 & 50 & 11 \\
\hline ROP Mazowieckie & 95.3 & 73.97 & 55 & 85 & 30 & 77 & 79 & 9 \\
\hline ROP Opolskie & 16.0 & 11.42 & 35 & 85 & 50 & 75 & 81 & 17 \\
\hline ROP Podkarpackie & 94.5 & 72.40 & 11 & 85 & 78 & 74 & 83 & 18 \\
\hline ROP Podlaskie & 58.4 & 45.85 & 64 & 85 & 21 & 76 & 75 & 7 \\
\hline ROP Pomorskie & 41.9 & 33.06 & 74 & 85 & 11 & 80 & 80 & 5 \\
\hline ROP Śląskie & 117.7 & 95.75 & 74 & 85 & 11 & 80 & 80 & 5 \\
\hline ROP Świętokrzyskie & 37.1 & 22.06 & 28 & 85 & 57 & 78 & 83 & 13 \\
\hline ROP Warmińsko-mazurskie & 12.6 & 8.41 & 46 & 60 & 14 & 59 & 60 & 3 \\
\hline ROP Wielkopolskie & 79.6 & 53.04 & 51 & 81 & 30 & 66 & 67 & 9 \\
\hline ROP Zachodnio-pomorskie & 28.9 & 17.64 & 55 & 72 & 17 & 67 & 70 & 5 \\
\hline All OPs & 1070.2 & 774.08 & 41 & 75 & 34 & 62 & 68 & 15 \\
\hline
\end{tabular}

Source: Author's elaboration based on the SIMIK 2007-2013 data.

the Holy Trinity (Church of Peace) - UNESCO heritage site, and the Orthodox Lublin-Chełm Diocese who did conservation, renovation and digitization of wooden churches and their equipment in the Małopolska, the Podkarpacie, the Lubelszczyzna and the Podlasie regions.

The total value of individual projects under both OP I\&Es ranged from PLN 7.8 million to PLN 31.2 million with a mean of 19 million. In general, the value of EU funding per project ranged from 6.6 million PLN to 26.2 million PLN, and the mean equalled nearly 20 million; however, these values varied if considered separately for 2007-2013 and 2014-2020 (Tables 1 and 3). The share of EU funding in the total value of projects ranged from $67 \%$ to $85 \%$ (Tables 2 and 4 ); however, most of the projects aimed at preservation of religious heritage ( 22 out of 40 ) were supported to the maximum level, i.e. $85 \%$ of eligible costs, and at the same time $85 \%$ of total costs, as there were no non-eligible costs in those projects.

Since 2007 the majority of projects aimed at preservation of religious heritage were co-financed by EU funding under regional operational programmes. All the projects aimed at renovation, restoration or conservation of religious heritage, its digitalization or increasing its accessibility to visitors, similarly to projects listed above as examples for the OP I\&E. However, some of the projects under the ROPs also 
Rakowska, J. (2020). European Union funding for preservation of religious cultural heritage in Poland. Acta Sci. Pol. Oeconomia 19 (4), 113-120, DOI: 10.22630/ASPE.2020.19.4.47

Table 3. Descriptive statistics for EU funds supporting projects to preserve religious heritage under operational programmes 2014-2020 in Poland

\begin{tabular}{|c|c|c|c|c|c|c|c|c|}
\hline \multirow{2}{*}{ Source of EU funds 2014-2020 } & \multirow{2}{*}{$\begin{array}{l}\text { Number } \\
\text { of } \\
\text { projects }\end{array}$} & \multirow{2}{*}{$\begin{array}{c}\text { EU funds } \\
\text { total value } \\
\text { (million PLN) }\end{array}$} & \multicolumn{6}{|c|}{ EU funds per project (million PLN) } \\
\hline & & & $\min$ & $\max$ & range & $A V G$ & $M$ & $S D$ \\
\hline OP Infrastructure and Environment & 37 & 560.78 & 6.55 & 23.71 & 17.16 & 15.16 & 15.99 & 3.86 \\
\hline ROP Dolnośląskie & 21 & 33.49 & 0.17 & 5.43 & 5.26 & 1.59 & 1.00 & 1.51 \\
\hline ROP Kujawsko-pomorskie & 8 & 1.38 & 0.09 & 0.30 & 0.21 & 0.17 & 0.10 & 0.10 \\
\hline ROP Lubelskie & 29 & 55.16 & 0.36 & 6.98 & 6.62 & 1.90 & 1.56 & 1.48 \\
\hline ROP Lubuskie & - & - & - & - & - & - & - & - \\
\hline ROP Łódzkie & 6 & 25.75 & 0.71 & 14.78 & 14.07 & 4.29 & 2.28 & 5.27 \\
\hline ROP Małopolskie & 12 & 52.71 & 0.87 & 7.24 & 6.37 & 4.39 & 5.29 & 2.75 \\
\hline ROP Mazowieckie & 30 & 49.39 & 0.20 & 8.38 & 8.17 & 1.65 & 1.01 & 1.69 \\
\hline ROP Opolskie & 14 & 22.72 & 0.29 & 3.99 & 3.70 & 1.62 & 1.31 & 1.26 \\
\hline ROP Podkarpackie & 33 & 60.87 & 0.26 & 3.86 & 3.60 & 1.84 & 1.99 & 0.88 \\
\hline ROP Podlaskie & 50 & 28.35 & 0.06 & 6.28 & 6.22 & 0.57 & 0.20 & 1.13 \\
\hline ROP Pomorskie & 8 & 88.47 & 0.68 & 27.50 & 26.82 & 11.06 & 8.29 & 10.76 \\
\hline ROP Śląskie & 31 & 120.67 & 0.15 & 18.26 & 18.11 & 3.89 & 2.00 & 4.57 \\
\hline ROP Świętokrzyskie & 10 & 6.90 & 0.28 & 2.78 & 2.51 & 0.69 & 0.48 & 0.74 \\
\hline ROP Warmińsko-mazurskie & 47 & 84.23 & 0.07 & 12.29 & 12.22 & 1.79 & 0.70 & 2.48 \\
\hline ROP Wielkopolskie & 15 & 63.41 & 0.09 & 12.23 & 12.14 & 4.23 & 2.99 & 3.53 \\
\hline ROP Zachodnio-pomorskie & 19 & 34.56 & 0.10 & 3.00 & 2.90 & 1.82 & 2.46 & 1.08 \\
\hline All OPs & 370 & 1288.83 & 0.06 & 27.50 & 27.44 & 3.48 & 1.45 & 5.12 \\
\hline
\end{tabular}

Source: Author's elaboration based on SIMIK 2014-2020 data.

included installation of renewable energy sources at religious heritage sites.

Their total value ranged from PLN 0.7 million to PLN 40 million, and the share of EU funding in total costs ranged from only $11 \%$ to $85 \%$. The number, total cost of projects and the value of EU funding varied significantly in Polish regions. In 2007-2013 most projects for preservation of religious heritage were carried out in the Świętokrzyskie; however, the biggest value of EU funding was obtained by projects in the Śląskie. Beneficiaries in both these regions gained the best relation of EU funding to total costs of projects (Tables 1 and 2). The fewest projects were co-financed in the Lubuskie and the Łódzkie.
In 2014-2020 the biggest number of projects under ROPs was carried out in the Warmińsko-Mazurskie and the Podlaskie (47 and 50, respectively). Beneficiaries from the Śląskie obtained the highest total value of EU funding - PLN 120 million, while projects in the Pomorskie had the highest mean of EU funding per investment, i.e. PLN 11 million. There were no projects of this kind in the Lubuskie (Tables 3 and 4).

Taking into consideration who carried out the projects, the majority of investments in preservation of religious heritage were carried out by the Catholic Church and its institutions: in 2007-2013 they did $95 \%$ of all projects, and in 2014-2020 - so far $-92 \%$. Other beneficiaries were (in order by decreas- 
Rakowska, J. (2020). European Union funding for preservation of religious cultural heritage in Poland. Acta Sci. Pol. Oeconomia 19 (4), 113-120, DOI: 10.22630/ASPE.2020.19.4.47

Table 4. Share of EU funding in total value of projects to preserve religious heritage under operational programmes 2014-2020 in Poland

\begin{tabular}{|c|c|c|c|c|c|c|c|c|}
\hline \multirow{2}{*}{ Source of EU funds 2014-2020 } & \multirow{2}{*}{$\begin{array}{c}\text { Projects } \\
\text { total value } \\
\text { (million PLN) }\end{array}$} & \multirow{2}{*}{$\begin{array}{c}\text { EU funds } \\
\text { total value } \\
\text { (million PLN) }\end{array}$} & \multicolumn{6}{|c|}{ Share of EU funds in total value (\%) } \\
\hline & & & $\min$ & $\max$ & range & $A V G$ & $M$ & $S D$ \\
\hline OP Infrastructure and Environment & 674.83 & 30.72 & 67 & 85 & 18 & 83 & 85 & 4 \\
\hline ROP Dolnośląskie & 48.81 & 15.32 & 11 & 85 & 74 & 73 & 82 & 21 \\
\hline ROP Kujawsko-pomorskie & 2.21 & 5.60 & 47 & 85 & 38 & 70 & 74 & 16 \\
\hline ROP Lubelskie & 73.08 & 21.64 & 62 & 85 & 23 & 75 & 73 & 7 \\
\hline ROP Lubuskie & - & - & - & - & - & - & - & - \\
\hline ROP Łódzkie & 38.42 & 3.88 & 56 & 69 & 13 & 65 & 68 & 6 \\
\hline ROP Małopolskie & 84.16 & 7.54 & 45 & 70 & 25 & 63 & 65 & 7 \\
\hline ROP Mazowieckie & 73.50 & 21.04 & 48 & 80 & 32 & 70 & 75 & 10 \\
\hline ROP Opolskie & 31.46 & 10.09 & 38 & 85 & 47 & 72 & 77 & 15 \\
\hline ROP Podkarpackie & 74.11 & 27.04 & 71 & 85 & 14 & 82 & 83 & 3 \\
\hline ROP Podlaskie & 42.16 & 37.52 & 21 & 85 & 64 & 75 & 78 & 13 \\
\hline ROP Pomorskie & 126.27 & 5.56 & 46 & 85 & 39 & 69 & 69 & 15 \\
\hline ROP Śląskie & 147.77 & 25.38 & 66 & 85 & 19 & 82 & 85 & 5 \\
\hline ROP Świętokrzyskie & 9.94 & 6.89 & 44 & 75 & 31 & 69 & 74 & 10 \\
\hline ROP Warmińsko-mazurskie & 112.25 & 6.89 & 44 & 75 & 31 & 69 & 74 & 10 \\
\hline ROP Wielkopolskie & 45.17 & 11.65 & 33 & 85 & 52 & 78 & 82 & 13 \\
\hline ROP Zachodnio-pomorskie & 78.56 & 14.93 & 45 & 85 & 40 & 79 & 85 & 12 \\
\hline All OPs & 1662.72 & 282.12 & 11 & 85 & 74 & 76 & 80 & 12 \\
\hline
\end{tabular}

Source: Author's elaboration based on SIMIK 2014-2020 data.

ing number of projects in 2007-2013 and 2014-2020, jointly): Evangelical Church of the Augsburg Confession in Poland parishes (19), parishes and institutions of the Polish Autocephalous Orthodox Church (17), Baptist Union of Poland (4), Muslim Religious Community in Kruszyniany (1) and Benchen Karma Kamtsang Buddhist Association in Poland (1). Within this group of beneficiaries there was a significant increase in the number of investments by the Polish Orthodox Church only. The character of projects was the same for different groups of beneficiaries, which resulted from the aims of operational programmes.

From the point of view of the beneficiary the best relation of the obtained EU funding and the total value of the project is when EU funds comprise $85 \%$ of the total value. This optimal result was obtained by 65 projects in $2007-2013$ ( $23 \%$ of all) and by 232 in $2014-2020$ (63\% of all projects). Consequently, the mean value of EU funding per project in religious heritage increased from 3.12 to 3.48 million PLN and the mean share of EU funding per projects from $62 \%$ in $2007-2013$ to $72 \%$ in $2014-2020$. On the other hand, many projects obtained EU funding for a smaller share of the total value of projects, thus Pearson's correlation coefficients between the total value of projects and the share of EU funding in the total value is positive and weak $r_{x y}=0.11(p=0.004$; $\alpha<0.005)$. 


\section{CONCLUSIONS}

European Union funding is a source of co-financing that does not need to be paid back, addressed to a wide range of beneficiaries carrying out projects aimed at local and regional development. The dynamic relation between religious heritage, tourism and development is the reason why the EU also supports preservation of religious heritage.

In consecutive financial perspectives of 2007-2013 and 2014-2020, Polish beneficiaries carried out 618 projects resulting in preservation of religious cultural heritage and co-financed by EU funding under operational programmes. Although these projects comprise a very small share of all projects co-financed by EU structural funds, we can observe an increase in the number of these investments in consecutive financial perspectives. There is also a significant increase in the number of projects that obtained the best relation of EU funding to their total value, i.e. $85 \%$.

All the projects were aimed at renovation, restoration or conservation of religious heritage, its digitalization or increasing its accessibility to visitors. However, some of the projects under ROPs also included installation of renewable energy sources at religious heritage sites.

The number, total cost of projects and the value of EU funding varied significantly in Polish regions, from the poorest outcome in the Lubuskie with only one project, to the best outcome in the Podlaskie with 59 projects.

The majority of projects were carried out by the Catholic Church and its institutions, less than $4 \%$ of projects by the parishes of the Evangelical Church of the Augsburg Confession in Poland, parishes and institutions of the Polish Autocephalous Orthodox Church, Baptist Union of Poland, and single projects by Muslim Religious Community and Benchen Karma Kamtsang Buddhist Association in Poland.

Summing up, although the projects aimed at preservation of religious heritage still make a very small share of all investments under operational programmes, their increasing number and improving relation between EU co-funding and total value of projects prove that more and more beneficiaries have been using this source in an increasingly effective way.

\section{REFERENCES}

Cohen, E.H. (2006). Religious tourism as an educational experience. [In:] T. Daniel, O. Dallen (Eds.), Tourism, Religion and Spiritual Journeys. Routledge Taylor \& Francis Group, London-New York.

Fadare, O.S., Benson, E.I. (2015). Case Stud 4: The Consumption and Management of Religious Tourism Sites in Africa. [In:] R. Raj, K.A. Griffin (Eds.), Religious Tourism and Pilgrimage Management: An International Perspective. CABI, Wallingford.

Hełpa-Liszkowska, K. (2013). Dziedzictwo kulturowe jako czynnik rozwoju lokalnego. Studia Oeconomica Posnaniensia, 1 (6), 5-18.

International Council on Monuments and Sites (1999). International cultural tourism charter. International Council on Monuments and Sites, México.

Jackowski, A. (2005). Główne problemy turystyki religijnej na świecie. [In:] W.W. Gaworecki (Ed.), Turystyka religijno-pielgrzymkowa. Wyższa Szkoła Turystyki i Hotelarstwa w Gdańsku, Gdańsk.

Kowalski, T., Ruszkowski, J.M. (2011). Miejsce kultu religijnego jako czynnika atrakcyjności turystycznej regionu na przykładzie Sanktuarium w Piekarach Śląskich. Zeszyty Naukowe Uniwersytetu Szczecińskiego, 647. Ekonomiczne Problemy Usług, 65, 71-83.

McKercher, B., Cross, H. du (2012). Cultural Tourism: The Partnership Between Tourism and Cultural Heritage Management. Routledge Taylor \& Francis Group, London-New York.

Małek, J. (2003). Turystyka kulturowa jako czynnik rozwoju lokalnego. Prace i Studia Geograficzne, 32, 13-34.

Ministerstwo Sportu i Turystyki Rzeczypospolitej Polskiej MSiT RP(2015). Program Rozwoju Turystyki do 2020 r. Załącznik do uchwały nr 143/2015 Rady Ministrów z dnia 18 sierpnia 2015 r. w sprawie przyjęcia „Programu Rozwoju Turystyki do 2020 roku".

Pytel, S. (2010). Rola turystyki kulturowej w rozwoju gmin województwa śląskiego. Krajobraz a Turystyka. Prace Komisji Krajobrazu Kulturowego, 14, 273-282.

Raj, R., Griffin, K. (2015). Introduction to Sacred or Secular Journeys. [In:] R. Raj, K.A. Griffin (Eds.), Religious Tourism and Pilgrimage Management: An International Perspective. CABI, Wallingford.

Richards, G. (2001). Cultural Attractions and European Tourism. CABI, Wallingford.

Rohrscheidt, A.M. von (2011). Faktyczna dostępność turystyczna obiektów sakralnych jako problem turystyki religijnej w Polsce. Zeszyty Naukowe Uniwersytetu Szczecińskiego, 647. Ekonomiczne Problemy Usług, $65,35-57$. 
Smith, M.K. (2009). Issues in Cultural Tourism. Routledge Taylor \& Francis Group, London-New York.

Sołjan, I. (2007). Studia nad turystyką. Tradycje, stan obecny i perspektywy badawcze. [In:] Studia nad turystyką. Tradycje, stan obecny i perspektywy badawcze. Vol. 1. Instytut Geografii i Gospodarki Przestrzennej Uniwersytetu Jagiellońskiego, Kraków, 289-296.

Throsby, D. (2016). Tourism, Heritage and Cultural Sustainability: Three 'Golden Rules'. [In:] L.F. Girard,
P. Nijkamp (Eds.), Cultural Tourism and Sustainable Local Development (New Directions in Tourism Analysis). Routledge, London.

Vukonić, B. (1998). Religious Tourism: Economic Value or an empty Box? Zagreb International Review of Economics \& Business, 1 (1), 83-94.

Vukonić, B. (2002). Religion, Tourism and Economics: A Convenient Symbiosis. Tourism Recreation Research, $27,59-64$.

\section{FUNDUSZE UNII EUROPEJSKIEJ DLA ZACHOWANIA RELIGIJNEGO DZIEDZICTWA KULTUROWEGO W POLSCE}

\section{STRESZCZENIE}

Ze względu na istnienie związku między religijnym dziedzictwem kulturowym, turystyką i rozwojem regionalnym Unia Europejska wspiera zachowanie religijnego dziedzictwa kulturowego poprzez udostępnianie funduszy polityki regionalnej realizowanych w ramach programów operacyjnych. Celem badań było określenie i analiza głównych efektów tego wsparcia na podstawie danych jakościowych i ilościowych z bazy SIMIK 2007-2013 oraz centralnego systemu teleinformatycznego (CST) SL2014 na lata 2014-2020. Wyniki wskazują, że 618 projektów mających na celu zachowanie religijnego dziedzictwa kulturowego w Polsce miało bardzo mały udział w liczbie wszystkich inwestycji w ramach programów operacyjnych. Miały też niewielki udział w całkowitej wartości wszystkich projektów i w całkowitej wartości pozyskanych środków UE. Porównując jednak perspektywę finansową 2007-2013 oraz 2014-2020, obserwuje się wzrost liczby takich projektów oraz odsetka tych, które uzyskały najlepszą relację środków unijnych do ich całkowitej wartości, tj. 85\%.

Słowa kluczowe: religijne dziedzictwo kulturowe, fundusze unijne, rozwój lokalny, turystyka 